\title{
The Contribution of Shaykh Muhammad Arsyad Al-Banjari in Spreading Islam in Nusantara
}

\author{
Dzulkifli Hadi Imawan \\ Universitas Islam Indonesia \\ dzulkifli.hadi.imawan@uii.ac.id
}

\begin{abstract}
This study will examine the contribution of Shaykh Muhammad Arsyad Al-Banjari in grounding Islam in the archipelago in the 18th century AD. He had a major contribution in grounding Islam in Nusantara in the 18th century AD. He left a great legacy in the form of scholarly works in various funun (Kitab Kuning) and also Pesantrens. Therefore, this study is to examine how far the contribution of Shaykh Muhammad Arsyad Al-Banjari in grounding Islam in Nusantara through the Kitab Kuning and his Pesantren in the 18th century AD. This study is a qualitative with a historical approach and a research library. The results of this study state that Shaykh Muhammad Arsyad Al-Banjari contributed greatly in grounding Islam in Nusantara through the Kitab Kuning and also through the Pesantren Dalam Pagar which produces many national figures to date.
\end{abstract}

Keywords: Kitab Kuning, Pesantren, Syaikh Arsyad Al-Banjari, Islam Nusantara

\section{Introduction}

Indonesia is an archipelagic country with islands that are connected by seas and oceans. One of the big islands is Borneo. Interestingly, Borneo is one of the famous islands since ancient times. According to Hamka's notes, since the 4th century AD, in East Borneo was established the Kutai Hindu Kingdom, led by King Mulawarman who is believed to still have a connection with the Hindu Kingdom in South India (Hamka, 2016).

In the aftermath, especially when Islam had begun to spread in several islands of the archipelago since the 8th century AD until the growth of the Peureulak Kingdom, and the Samudera Pasai Kingdom, more and more traders and scholars from Arabia came to the islands in the archipelago (Imawan, 2021). One of the islands they visited is the island of Borneo as it was one of the main destinations of traders from Arab countries. One of the Arab scholars named Shaykh Syamsuddin alAnsari al-Damasyqi; a scholar who came from Damascus, Syria, in the 14th century $\mathrm{AD}$ had visited this island and recorded it in his notebook entitled Nukhbatu al-Dahr 
fi 'Ajaib al-Barri wa al-Bahri (a gift of the age of wonders on land and oceans). He called the island of Borneo in his book the jazirah al-Ranji. The word al-Ranji is taken from the word al-Narajil, because Borneo was overgrown by coconut trees. He also called it the Burniyu Peninsula (Borneo) (Al-Damasyqi, 1881).

Two centuries later, came a Portuguese named Tome Pires. In his notebook entitled Suma Oriental, he mentioned Borneo or Burney. The main island Borneo was surrounded many small and large islands such as Tanjungpura, Laue, Kedawangan (Quedomdoam), Sampit (Samper), Kotabaru (Cate), and Pamukan (Pamuca). These islands produced a lot of gold with low metal, camphor, honey, wax, rice, and sago which were commonly traded to Malacca (Pires, 2016).

According to Harun, in the 12th century AD, when the Peureulak kingdom had grown in Aceh, the Dipa Kingdom in Borneo was founded by Empu Jatmika or known as Maharaja at Canti after he built the Great Temple on Hujung Tanah Island (designation for the island of Borneo at that time). In a short time, he was able to conquer areas in Borneo such as Batang Tabalong, Batang Balangan, Batang Petap, Batang Alai, Amandit, and Labuhan Emas as part of his power. But during the reign of the third king, Raja Sari Kabirdan moved the government capital of Nagara Dipak to the southern part, namely Muara Bahan and moved for the last time to Banjarmasin. After King Sari Kabirdan died, he was succeeded by his crown prince named Maharaja Sukarama. However, in the aftermath, there was a power struggle among the three sons of Maharaja Sukarama, namely Prince Mangkubumi, Prince Tumenggung, and Princess Galuh.

One of the causes of the power struggle was that Maharaja Sukarama, before he died, made a will to Patih Aria Trenggana so that the next king would be his grandson, Prince Samudera. But prince Mangkubumi took over the kingdom until he was killed by his brother Prince Tumenggung who also wanted that power. Prince Tumenggung tried to prevent Prince Samudera from becoming king by killing him. However, Prince Samudera managed to escape from the palace by heading to the coastal areas of Serapat, Belandian, Kuin, Balitung, and Banjar. In these places, Prince Samudera was able to make diplomacy with the rulers of the areas and succeeded in establishing cooperation with them, which in turn he was appointed as their king (Harun, 1995). 
Prince Samudera tried to establish good cooperation with the Demak Kingdom in Java, which then sent 40,000 troops to face his uncle; Prince Tumenggung who had usurped the power of the Daha State from him. So in 1526, there was a battle between Prince Samudera's troops who were assisted by Muslim troops from Demak and Prince Tumenggung's troop. Prince Samudera won the battle. This was what attracted Prince Samudera to convert to Islam. After converting to Islam, he was titled Sultan Suriansyah. He then made his kingdom an Islamic kingdom (Buseri, 2012).

Interestingly, according to Kyai Saifuddin Zuhri, Islamization in Borneo also could not be separated from the role of Sunan Giri who used to sail to Borneo to trade and also spread Islam. As told, when Sunan Giri was trading in Kalimantan, he liked to distribute his merchandise for free to the poor (Zuhri, 1981). Since then, more and more people of the island of Borneo converted to Islam, especially after the establishment of Banjar Islamic Kingdom since the Suriansah reign which was then centered in Banjar during the time of his son Sultan Rahmatullah, until the period of Sultan Tahlilullah and Sultan Tahmidullah who had close relations with scholars such as Shaykh Muhammad Arsyad Al-Banjari.

Shaykh Muhammad Arsyad Al-Banjari was a great scholar, knowledgeable, and contributed to the preaching of Islam to the people of Banjar, Borneo, Indonesia. Therefore, this study tries to analyze the contribution of Shaykh Arsyad Al-Banjari in spreading Islam and producing Islamic intellectuals in Borneo.

This study differs from previous studies by some researchers such as Fathullah Munadi in his work "Mushaf Qiraat Sheikh Muhammad Arsyad Al-Banjari in the History of Qiraat Nusantara" (Munadi, 2010). Abd Rochim al-Audah in "Political Thought of Sheikh Muhammad Arsyad Al-Banjari and Its Relevance for the Construction of Legal Politics" (Al-Audah, 2019), Andi Eka in "Tasawwuf in the View of Shaykh Arsyad Al-Banjari" (Putra, 2013) and also Muslich Shabir in "The Thought of Shaykh Arsyad Al-Banjari About Zakat" (Shabir, 2009). This is a qualitative study with a historical approach and the study of literature (library research).

\section{Results and Discussion}

\section{The Biography of Shaykh Muhammad Arsyad Al-Banjari}

Shaykh Muhammad Arsyad Al-Banjari is the son of Abdullah and Siti Aminah. He was born on 15 Safar 1122 H/19 March 1710 AD in Banjarmasin 
during the reign of Sultan Hamidullah or Sultan Tahmidullah bin Sultan Tahlilullah (1700-1734 AD). His father was from India who lived in the village of Lok Gabang (now part of the Astambul sub-district, Banjar district) who worked as a carver in the palace (Imawan, 2018a).

The intelligence of Shaykh Arsyad's, who as a child was named Ja'far, made Sultan Tahlilullah admire him so that the Sultan was pleased to adopt him and did best for his education such as inviting in to the palace religious teachers to educate him religious sciences. When he was 30 years old, Shaykh Arsyad married a pious woman named Bajut. But not long after that, he asked her permission to study in Mecca for imperceptibly 35 years (Dahlan, 2015).

In Makkah, Shaykh Arsyad Al-Banjari met Shaykh Abdusshamad alFalimbani, Shaykh Abdurrahman al-Mashri, Shaykh Abdul Wahhab Bugis (Imawan, 2018b). Shaykh Abdurrahman Shiddiq Al-Banjari in Syajarah Arsyadiyah said that Shaykh Arsyad and his companions studied with Shaykh Athaillah (Al-Banjari, 2017). According to Jabarti, Shaykh Athaillah ibn Athaillah ibn Ahmad al-Azhariy was an al-Azhar alumnus who became a great scholar and expert in the field of Shafi'i Fiqh in Mecca (Jabarti, 1997).

In Medina, Shaykh Arsyad also studied with Shaykh Muhammad bin Abdulkarim al-Samman, a murshid of the Sammaniyah School of Sufism. He also studied with Shaykh Muhammad bin Sulaiman al-Kurdi who was also an expert on Shafi'i Fiqh in the city of Medina (Al-Banjari, 2017)

Abu Daudi mentioned that in addition to studying with Shaykh Athaillah, Shaykh Samman, and Shaykh Sulaiman Kurdi, Shaykh Arsyad Al-Banjari's other teachers were Shaykh Ahmad Abdul Mun'im al-Damanhuri, Shaykh Muhammad Murtadla al- Zabidi, Shaykh Hasan Akisy al-Yamani, Shaykh Salim bin Abdullah al-Bashri, Shaykh shiddiq bin Umar Khan, Shaykh Abdullah al-Hijazi al-Syarqawi, Shaykh Abdurrahman bin Abdul Aziz al-Maghribi, Shaykh Abdurrahman bin Abdul Mubin Pauh Bok al- fathani, Shaykh Abdul Ghani bin Muhammad Hilal, Shaykh Abid al-Sindi, Shaykh Abdul Wahhab al-Thanthawi, Shaykh Maulana Sayyid Abdullah mirghani, Shaykh Muhammad bin Ahmad al-Jauhari, Shaykh Muhammad Zain bin Fakih jalaluddin Aceh (Daudi, 1996).

Syajarah Arsyadiyah mentioned that when Shaykh Arsyad was about to go to Egypt, Sheikh Muhammad bin Sulaiman al-Kurdi adivised him to return to 
Nusantara because he had a lot of knowledge so he could teach Islam there. Before returning to the Nusantara archipelago, Shaykh Arsyad and his friends went to Mecca to perform I'tikaf in the month of Ramadan at the Grand Mosque (Masjid al-Haram). After that, he returned to the archipelago and stopped in Betawi (Jakarta) and met Shaykh Abdul Qahhar; the leader of the Betawi ulama at that time (Al-Banjari, 2017).

After two months, Shaykh Arsyad left Betawi and continued his journey to Martapura. After 35 years, in the month of Ramadan 1186 H/December 1772 AD, Shaykh Arsyad finally returned to Martapura and met his family. At that time, his daughter named Syarifah had married a Malay named Uthman and had a son named Muhammad As'ad. Her husband had passed away, so Shaykh Arsyad married his daughter to his best friend named Shaykh Abdul Wahhab Bugis and from this marriage was born a child called Fatima. Shaykh Arsyad started his preaching to his family; by teaching his grandchildren who had many scholars from his descendants; both as ulama, mufti, lecturers, community leaders, to military officers (Al-Banjari, 2017).

2. The Contribution of Shaykh Muhammad Arsyad Al-Banjari in Spreading Islam in Nusantara Archipelago

\section{First, Establishing Pesantren as a Center for Ulama' Caderisation}

Daudi said that in $1761 \mathrm{AD}$, Sultan Tahmidullah provided a piece of land on the banks of the Martapura River to Shaykh Arsyad Al-Banjari for his house and at the same time a place of education. As time went by, this place became a village and center of religious education in the Banjar Kingdom. Not only that, the place was also managed as a good agricultural land to support the community's economic activities and also the education held by Shaykh Arsyad. Assisted by his best friend who was also his son-in-law, Sheikh Abdul Wahhab Bugis, the village later became a magnet for students who wanted to learn and explore Islam so this place was known as Kampung Dalam Pagar or also the kawah Candradimuka; a place for nurseries and development of scholars (Dawudi, n.d).

In this pesantren or education center, Shaykh Arsyad taught his descendants and also his students the sciences of Islam under the manhaj of Ahlu al-Sunnah wa al-Jamaah in theology, Madzhab Syafii in Sharia, and the Sammaniyah in 
Tarekat or Islamic mysticism as he followed and learned from the Haramain scholars. Shaykh Arsyad himself had 30 children from his 11 wives. Among his descendants who inherited his knowledge were Shaykh Muhammad As'ad, Shaykh Muhammad Yasin, Shaykh Fatimah bint Abdul Wahhab Bugis, and Shaykh Ideris bin Shaykh Zainal Abidin.

Abu Dawudi mentioned that among of the descendants of Shaykh Arsyad; both biological and ideological, who contributed greatly to the spread of Islam were Shaykh Qadli H. Abu Naim bin Shaykh Muhammad Arsyad Al-Banjari, Shaykh Jamaluddin bin M. Arsyad Al-Banjari; grandson KH. Muhammad Yusuf bin KH. Muhammad Thasin (the founder of a pesantren in Pontianak), Shaykh Ahmad bin Haji Abdullathif (a preacher in Brunei Darussalam) who is known as Dato Ahmad Mufti Banjar, KH. Abu Talhah bin Mufti Muhammad As'ad bin Syarifah bint M. Arsyad (a preacher in East Borneo), KH. Abu Hamid bin Muhammad As'ad bin Syarifah bin M. Arsyad Al-Banjari, KH. Sa'aduddin KH. Muhammad Arsyad bin M. As'ad, KH. Ahmad bin M. As'ad. All of them were the children and grandchildren of Shaykh Arsyad Al-Banjari.

Among the students of Shaykh Arsyad were Sultan Tahmidullah II and Sultan Adam al-Watsiq Billah. The Sultans of Banjar strongly supported the spread of Islam carried out by Shaykh Arsyad Al-Banjari in South Borneo and its surroundings so that by the Umara and Ulama cooperation, Islam could be widely accepted by the people of Borneo, Kalimantan.

Interestingly, among the descendants of Shaykh Arsyad Al-Banjari, his grandson was one of the scholars who taught in the Grand Mosque of Mecca, namely Shaykh Ali ibn Abdillah ibn Muhammad Arsyad ibn Abdillah Al-Banjari al-Makki. His biography was recorded by Abdullah al-Mu'allim in the biography of the scholars of Mecca, A'lam al-Makkiyyin, he explained that Shaykh Ali bin Abdullah bin Muhammad Arsyad Al-Banjari was born in Mecca in 1285 H/1868 A.D. Before studying to the Haramayn scholars, he had memorized many subjects such as Islamic jurisprudence, nahwu, sharaf and others. After that, he delved deeper into and studied the above sciences to Sayyid Abu Bakar Syatha. He studied hadith and Islamic jurisprudence to Shaykh Said Yamani, and studied the science of Astronomy to Shaykh Yusuf al-Khayyath. 
He also studied with Sayyid Husain bin Muhammad al-Habsyi, Sayyid Alawi bin Ahmad Saqqaf, Mufti Abid bin Husain bin Ibrahim al-Maliki, and also Shaykh Muhammad Mahfuzh Al-Tarmasi. Like his father and grandfather, Shaykh Ali AlBanjari also had the opportunity to teach at the Grand Mosque of Mecca. In addition, he also taught his students in his house located in Syamiyah. Among his writings is the book "Al-Kaukab Al-Barri Fi Tsabat Al-Banjari". He died 1348 H/1930 A.D. (Imawan, 2018) (Mu'allimiy, 2000).

The Pesantren Dalam Pagar established by Shaykh Muhammad Arsyad AlBanjari and Sheikh Abdul Wahhab Bugis in Martapura was one of the pioneers of Pesantrens or pesantren in Borneo which still exists and produces many national figures. According to Emroni, one of the reasons is its adaptability to the needs of the era without leaving the old educational values and characteristics of the pesantren since it was first founded by Shaykh Arsyad Al-Banjari. In addition to the Diniyah system, in 1931 AD, the Pesantren Dalam Pagar had a formal system which was initiated by Shaykh Muhammad Thoha, the fourth descendant of Shaykh Al-Banjari and named the Pondok Pesantren Al-Istiqamah. Then in the 1950s, the pesantren was renamed by Shaykh Muhammad Salman with Pondok Pesantren Asy-Syar'iyyah, and in 1960 it was renamed with Pondok Pesantren Sullam al-'Ulum by Shaykh Anang Sya'rani Arif. Despite changing names, the Islamic religious education system at the pesantren still maintains the classical system; halaqah, sorogan, lectures, and morale-building approaches as in the beginning of the establishment (Emroni, Muthmainah, \& Lathifaturrahmah, 2014).

It can be concluded that, as the initial founder, Shaykh Arsyad Al-Banjari is proven to have a great contribution in introducing the Pesantren system as a means to educate children of Borneo in understanding Islamic sciences, from the 18th century AD until now.

\section{Second, Teaching Kitab Kuning; Literacy Jihad of Shaykh Muhammad Arsyad Al-Banjari}

In addition to producing notable scholars, Shaykh Arsyad Al-Banjari also contributed greatly in reviving literacy by writing books as a means of da'wah. He is listed as a prolific scholar in writing books. He wrote books in various disciplines. One of the well-known books of Shaykh Arsyad Al-Banjari among 
ulama and students until now is the book Sabil al-Muhtadin li al-Tafaqquh fi Amri al-Din; a book in the field of Shafi'i jurisprudence written to explain the book of al-Shirath al-Mustaqim written by Shaykh Nuruddin al-Raniri, an Acehnese scholar in the 17th century AD. This book was written in Malay language on the request of Sultan Tahmidullah bin Sultan Tamjidullah in $1193 \mathrm{H}$.

In only two years, $1195 \mathrm{H}$ (1778-1780 AD), the book was completed in two thick volumes, which then in $1300 \mathrm{H} / 1882 \mathrm{AD}$ the book, by the efforts of Sheikh Ahmad al-Fatani, was successfully published in Mecca, Turkey, and Cairo together with the publishing of the book Turjuman al-Mustafid by Shaykh Abdurrauf al-Sinkili. The book Sabil al-Muhtadin had a great influence in maintaining Syafii fiqh in the archipelago in the 18th century and later, and had also spread to its neighborhood places such as the Philippines, Malaysia, Singapore, Thailand, Indonesia, Brunei, Cambodia, Vietnam, and Laos. Even today, the book is still being studied in surau (worship places, smaller than mosque) in Banjar and Malaysia. In writing Sabil al-Muhtadin, Shaykh Arsyad referred a lot to the books of the Shafi'i madhhab such as Syarh al-Minhaj by Shaykhul Islam Zakaria al-Ansari and Khatib Syarbini, Tuhfah al-Muhtaj by Ibn Hajar al-Haitami, al-Mardliyah, Nihayah Imam Ramli's al-Jamal and other Shafi'i books (Al-Banjari, nd).

In the field of Islamic jurisprudence, Shaykh Arsyad also wrote Kitab alFaraidl, a book that discusses the law of inheritance in Islam covering heirs, inheritance property, and conditions related to inheritance. In addition, Khasyiah Fath al-Jawad, is Al-Banjari's effort in translating the book Fath al-jawwad by Imam Ibn Hajar al-Haitami in Malay language so that his students and the Banjar community can easily understand it. His other book of Islamic jurisprudence is called Luqthatu al-'Ajlan, explaining the laws about women such as menstruation, childbirth, and istihadlah. This book was written in 1192 H/1778 A.D.

Shaykh Arsyad also wrote the book Fatawa Sulaiman al-Kurdi which contains a collection of fatwas of Shaykh Islam Imamul Haramayn Muhammad bin Sulayman al-Kurdi on various questions asked to him such as the policy of the king in collecting taxes and fines for violators of the law (those who missed Friday prayers intentionally) as well as various other important issues (Dahlan, 
2015). These books show that Shaykh Muhammad Arsyad Al-Banjari was a scholar of Islamic jurisprudence following Shafi'i School.

In addition to Islamic jurisprudence, Shaykh Arsyad also wrote a lot on theology of Ahlussunnah wal Jama'ah. Like his book entitled Tuhfah al-Raghibin fi Bayani Haqiqah Iman al-Mu'min wa Ma Yufsiduhu min Riddati al-Murtaddin. This book explains the three main things of faith, namely the nature of faith, the things that can destroy faith, and the deeds that can make a person an apostate and its consequences. This book was written in 1188 H/1774 A.D (Al-Banjari, n.d).

In the field of theology, Shaykh Arsyad also wrote the book Majmu', AlBanjari's explanation on the basics of Islam including the issue of asy'ariyah faith, the obligatory and impossible attributes of Allah and His Messenger which are then called the twenty attributes. The Majmu' also contains the issue of Sharia which includes the five pillars of Islam; shahada, prayer, zakat, fasting, and hajj. It also discusses the issues of Sufism and morality covering the reality of the soul, praiseworthy qualities, and deeds that can bring one closer to Allah. This book is still a manuscript and has not been published. Al-Banjari specially explained the twenty attributes of Allah in his book called Ushul al-Din written in $1188 \mathrm{H} / 1774$ AD.

The book Risalah Qaul al-Mukhtashar fi 'Alamat al-Mahdi al-Muntazhar, a book that explains the signs of the imminent appearance of Imam Mahdi; lineage, name, nickname, father's name, life history, karamah (exceptional gift endowed by God to Sufi saint), place of birth, place of residence and also an explanation of some signs of doomsday. In this book, Shaykh Arsyad referred a lot to the book of Sayyid Ja'far al-Barjanji, also the book of the treatise of Shaykh Abdul Qadir alFakihiy who quoted a lot from the Risalah of Imam Ibn Hajar al-Haitamiy. He also referred to the work of Shaykh Ibn Yusuf al-Muqaddasi in his book Bahjah alNazhirin, and referred to the book 'Ajaib al-Malakut by al-Kisaiy, also Syarh Qashidah by Shaykh Ahmad al-Qusyasyi al-Madani. This book was written on Thursday 22 Rabiul Awwal in the year 1196 H/1782 AD. This book was published in $1356 \mathrm{H} / 1937 \mathrm{AD}$, then in 2017 was republished by the publisher Khazanah Fathaniyah in Malaysia (Al-Banjari, 2017a). 
Shaykh Arsyad also wrote a book on theology and Sufism called Fath alRahman bi Syarh Risalah al-Waliy al-Ruslan by Al-Banjari. This book was written by Shaykh Arsyad as an explanation (syarh) of the book al-Risalah al-Raslaniyyah written by Imam Arif Billah Raslan al-Damasyqi. This book explains about monotheism (faith) as noted by Al-Banjari in his preface. Haji Wah Mohammad Shaghir mentioned that the monotheism that Shaykh Arsyad meant in this book is monotheism in the view of the scholars of mysticism or tasawwuf (Sufi). This book discusses tasawwuf from basic to advance materials which refers a lot to the opinions of Hujjatul Islam Imam Ghazali. Shaykh Arsyad also explains in this book the kinds of tauhid such as tauhid fi al-af'al, tauhid fi al-shifat, tauhid fi aldzat, also tauhid al-'awwam, tauhid al-khawwash, tauhid khawwash alkhawwash.

This book was written by Al-Banjari in Malay language and was once published by Hasanu Banjarmasin bookstore, was second printed in 1405 H/1985 AD with 91 pages thick. The publisher Khazanah Fathaniyah Malaysia published the book based on the collection of books by Haji Wan Muhammad Shaghir Abdullah in 2017 (Al-Banjari, 2017). In study of Islamic mysticism or tasawwuf, Shaykh Arsyad wrote Kanz al-Ma'rifah which discusses the practices in the tariqat such as maqamat and dhikr. This book is still in the form of a manuscript and has not been printed (Dahlan, 2015).

Shaykh Arsyad Al-Banjari also wrote a manuscript of the Qur'an in 1779 AD which consists of three volumes, and each volume consists of ten chapters. The size of the manuscript's page is $57 \mathrm{~cm}$ wide and $63 \mathrm{~cm}$ long. Currently, volume one of the manuscripts is in the collection of the Regional Museum of South Kalimantan, Banjar Baru, and the volume two and three are in Dalam Pagar and are being cared for by Abu Dawudi who is a descendant of Shaykh Arsyad. It is believed that Shaykh Arsyad started writing the manuscripts of the Qur'an in $1193 \mathrm{H}$, which coincided in 1779 AD. This manuscript includes the manuscripts written using Naskhi script with the Ottoman standard according to the Hafs transmission (d. $180 \mathrm{H}$ ) from Imam Ashim (w. $127 \mathrm{H}$ ); the same period of Imam Abu Hanifah (d. 150 H), and Imam Malik (d. 179 AD) (Munadi, 2010).

These works show the depth of Shaykh Arsyad Al-Banjari's knowledge and his expertise in various fields of knowledge such as Sharia (Islamic law), aqidah 
(theology) and also Sufism (Islamic mysticism) or morals. Interestingly, most of these works are still being printed by various publishers in Indonesia, Malaysia, and even Egypt.

\section{Conclusion}

Islam has been spread on the island of Borneo since the 14th century AD by many scholars and also traders from Arab countries who arrived in the Nusantara archipelago, and anchored on the island of Borneo. The spread of Islam played a major role in the process of establishing Islamic kingdoms in Borneo, including the Banjar Kingdom. One of the ulama figures who played a major role in the process of Islamization (Spreading Islam) in Banjar was Shaykh Arsyad Al-Banjari. He is one of the great scholars in Borneo as well as in Indonesia. He have had notable influence since the 18th century AD which is still felt until today because one of his da'wah strategies was by building Pondok Pesantren Dalam Pagar and teaching the Kitab Kuning under the theology of Ahlussunnah wal Jamaah, Madzhab Syafii and Sunni tasawwuf. His efforts proved his success in educating his students to become national figures who always provide benefits to all levels of society.

\section{Bibliography}

Al-Audah, A. R. (2019). Pemikiran Politik Syekh Muhammad Arsyad Al-Banjari dan Relevansinya bagi Pembinaan Politik Hukum. Al-Mashlahah Jurnal Hukum Islam dan Pranata Sosial, 7(02), 211-234. https://doi.org/10.30868/am.v7i02.594

Al-Banjari, S. M. A. (2017). Fathu al-Rahman bi Syarh Risalah al-Waliy al-Ruslan. Malaysia: Khazanah Fathaniyah.

Al-Banjari, S. M. A. (2017a). Risalah Qaul al-Mukhtashar fi 'Alamat al-Mahdi alMuntazhar. Malaysia: Khazanah Fathaniyah.

Al-Banjari, S. M. A. (n.d.-b). Sabil al-Muhtadin. Surabaya: Al-Hidayah.

Al-Banjari, S. M. A. (n.d.). Tuhfah al-Raghibin fi Bayan Haqiqah Iman al-Mukminin wa ma Yufsiduhu min Riddah al-Murtaddin. Surabaya: Haramain.

Al-Damasyqi, S. A. A. M. A. T. al-Anshari. (1881). Nukhbah al-Dahr fi 'Ajaib al-Barr wa al-Bahr. Turs: Matba'ah Imritoriyah.

Bin Muhammad Afif Al-Banjari, S. A. S. (2017). Risalah Syajarah al-Arsyadiyah wa ma Ulhiqa biha. Malaysia: Khazanah Fataniyah. 
The Contribution of Shaykh Muhammad Arsyad Al-Banjari...

Buseri, K. (2012). Kesultanan Banjar dan Kepentingan Dakwah Islam. Al-Banjari : Jurnal Ilmiah Ilmu-Ilmu Keislaman, 11(2). https://doi.org/10.18592/AlBanjari.v11i2.457

Dahlan, B. (2015). Pemikiran Sufistik Syaikh Muhammad Arsyad Al-Banjari (I). Yogyakarta: Pustaka Utama.

Daudi, A. (1996). Maulana Syaikh Muhammad Arsyad Al-Banjari Tuan Haji Besar. Martapura: Secretariat Madrasah Sullamul Ulum Dalam pagar.

Dawudi, A. (n.d.). Manaqib Maulana Syaikh Muhammad Arsyad Al-Banjari. Banjarmasin.

Emroni, E., Muthmainah, I., \& Lathifaturrahmah, L. (2014). | Emroni. Tashwir, Jurnal Penelitian Agama Dan Sosial Budaya, 1(2). https://doi.org/10.18592/jt.v1i2.165

Hamka, B. (2016). Sejarah Umat Islam (I). Jakarta: GIP.

Harun, M. Y. (1995). Kerajaan Islam Nusantara Abad XVI \& XVII (I). Yogyakarta: Kurnia Kalam Sejahtera.

Imawan, D. H. (2018a). Jalan dakwah ulama Nusantara di Haramain abad 17-20 M.

Imawan, D. H. (2018b). The Intellectual Network of Shaykh Abdusshamad AlFalimbani and His Contribution in Grounding Islam in Indonesian Archipelago at 18th Century AD. Millah: Jurnal Studi Agama, 18(1), 31-50. https://doi.org/10.20885/millah.vol18.iss1.art3

Imawan, D. H. (2021). The History of Islam in Indonesia; Kontribusi Ulama Membangun Peradaban dan Pemikiran Islam di Indonesia. Yogyakarta: Diva Press.

Jabarti, A. (1997). 'Ajaib al-Atsar fi al-Tarajim wa al-Akhbar. Kairo: Dar Kutub Mishriyah.

Mu'allimiy, A. (2000). A'lam al-Makkiyyin min al-Qarn al-Tsalits ila al-Qarn al-Rabi' 'Asyar al-Hijriy (I). Makkah: Muassasah Furqan.

Munadi, F. (2010). Mushaf Qiraat Syekh Muhammad Arsyad Al-Banjari dalam Sejarah Qiraat Nusantara. Al-Banjari : Jurnal Ilmiah Ilmu-Ilmu Keislaman, 9(1). https://doi.org/10.18592/Al-Banjari.v9i1.917

Pires, T. (2016). Suma Oriental. Yogyakarta: Penerbit Ombak.

Putra, A. E. (2013). Tasawuf dalam Pandangan Muhammad Arsyad Al-Banjari. AlAdyan: Jurnal Studi Lintas Agama, 8(2), 91-102. https://doi.org/10.24042/ajsla.v8i2.588

Shabir, M. (2009). Pemikiran Syekh Muhammad Arsyad Al-Banjari tentang Zakat dalam Kitab Sabîl al-Muhtadîn Analisis Intertekstual. Analisa: Journal of Social Science and Religion, 16(1), 1-18. https://doi.org/10.18784/analisa.v16i1.55

Tim MUI Kalsel, \& Tim LP2M UIN Antasari Banjarmasin. (2018). Ulama Banjar dari Masa ke Masa (I). Banjarmasin: Antasari Press.

Zuhri, K. S. (1981). Sejarah Kebangkitan Islam dan Perkembangannya di Indonesia. Bandung: Al-Ma'arif. 